\title{
The Re-branding Project: The Genealogy of Creating a Neolibeal Jane and Finch
}

\author{
SUZANNE NARAIN ${ }^{1}$ \\ Ontario Institute for Studies in Education, \\ University of Toronto
}

\begin{abstract}
This research examines the stigmas that have been given to the Jane and Finch area in Toronto, Ontario and the effects of re-branding the neighbourhood as "University Heights". The rebranding initiative started in 2006 and has rapidly changed the face of the Jane and Finch community with the development of new housing complexes and a subway expansion. Using a genealogical approach I trace the steps that were taken to develop "University Heights" to determine if a democratic process was used throughout the decision-making phases. I outline the key social, political and economic stakeholders that played a role in the re-branding project. In the context of neoliberal praxis, I use the public statements made by the stakeholders to unpack what the re-branding initiative entails and highlight whose interests it is likely to serve. This research calls attention to the ways in which residents of the Jane and Finch area will be affected by the gentrification of their neighbourhood. A critical race framework is used to uncover the neoliberal ideologies that have been fundamental to the creation of "University Heights". The crux of my project is to highlight the social injustices along the axis of race, class and gender, that are embedded in applying a neoliberal agenda in the Jane and Finch area.
\end{abstract}

The Jane and Finch area elicits a sense of belonging and vibrancy; it is an entry point to starting a life in Canada. Jane and Finch is celebrated for its diversity while simultaneously criminalized for its unruly youth, high poverty rates and dense population. The moniker "Jane

\footnotetext{
${ }^{1}$ Resident and activist in the Jane-Finch community
} 
and Finch" has become tainted in the public imaginary and is considered one of the most dangerous corridors in Canada (Richardson, 2008). Mass media perpetuates scenes of violence erupting within the under-resourced neighbourhood. To intervene with the plagued representations of Jane and Finch the project of re-branding the area to "University Heights" was created. The area commonly known as 'Jane and Finch' is a part of the Ward 8 district in Toronto, Ontario, has undergone many social and political changes since Councillor Anthony Perruzza won the 2006 municipal election for the Ward 8 district. Some of the recent changes include: planning to extend the subway line into the Jane and Finch area, developing the Village at York University, and the re-branding of Jane and Finch to "University Heights". According to Councillor Anthony Perruzza, the "re-branding will bring the community and the university together, continuing to fight the neighbourhood's reputation for violence and hopelessness" (Ros, 2007, para.1). Councillor Perruzza's discourse is consistent with the stigmatizing reputation generated by negative police and media representations (Richardson, 2008). Relying on the neo-liberal praxis of "revitalization", re-branding the Jane and Finch area to "University Heights" creates a dichotomous image of the area and validates an a priori stigma of the area. I will demonstrate in this paper that in addition to a host of other problems, such as gentrification, the re-branding of Jane and Finch has been a top-down initiative void of substantive community consultation or input. In order to create a new image of a community in which all members can find a sense of 'belonging' there should be equal involvement from local residents, grassroots organizations, and political stakeholders. The main goal of my research paper is to demonstrate how re-branding Jane and Finch to "University Heights" is a neoliberal project that undermines social justice. By elucidating the praxis of neoliberalism I demonstrate how neoliberal projects work to marginalize and gentrify communities by promoting the privatization of public spaces. 
The crux of my project is to highlight the social injustices that are embedded in applying a neoliberal agenda in the Jane and Finch area.

In my paper I present a textual and genealogical analysis of re-branding Jane and Finch to "University Heights". There have been many key stakeholders that have been a part of the rebranding process. These include: York University, York University Development Corporation, the Toronto Transit Commission, Tribute Communities (a housing developer), and the Toronto District School Board. I provide a genealogy of how the re-branding project came to life and examine the extent of influence exerted by various stakeholders in developing the "University Heights”. I contrast the positionality and power of politicians, governmental agencies, and economic stakeholders with that of local residents of the community. Throughout this paper, I highlight how the re-branding process has contributed to marginalizing community voices in political spheres and the resistance that came forward as a result. I also demonstrate how rebranding projects constitute a form of social injustice despite the fact its advocates claim the opposite.

\section{A Brief History of Jane and Finch}

Many immigrant families have settled in the Jane and Finch area over the last half century. Prior to the 1960s, a large percentage of the area's residents were comprised of Italian immigrants. However, as a result of rapid urban growth in Toronto, Jane and Finch underwent massive development by the Ontario Housing Commission (OHC) in the 1960s, altering the earlier ethnic/cultural composition of the neighbourhood. The post-1960s migration to the Jane and Finch area was predominantly from Asia, Africa, South America and the Caribbean (Richardson, 2008). The OHC built many high-rise apartment buildings and townhouses to accommodate the rising population. The immense production of affordable housing created an 
area that attracted a high immigrant, working class and urban population. This densely populated area has, over the last three decades, become a highly racialized space. As articulated by Cheryl Teelucksingh (2007) the term 'racialization' can be used to describe the racial composition of Canadian cities. Teelucksingh (2007) highlights that there are hidden racial tropes of marginality that exist within these spaces. Lower-income neighbourhoods in Toronto are often racialized, though this categorization is not only attributed to the amount of visible minorities that occupy these spaces. Rather, the 'racialization' of a space is attributed to many factors, including lack of social, economic and political resources (Teelucksingh, 2007). As Kay Anderson (1998) describes, "racial identities are often configured in spaces" (p. 202). Jane and Finch as a social location has become plagued with negative stereotypes. The racialization of Jane and Finch has resulted in the "othering" of the residents and has created an association of fear in the media, political discourse and popular beliefs. The fear and othering of residents produces a highly surveilled and policed environment.

The Jane and Finch community is known for having one of the highest proportions of youth, sole-supported families, refugees, immigrants, and public housing tenants of any community in Toronto (Richardson, 2008). The citizens in this community are largely categorized as the "urban poor" in the public imaginary. The regional media, police, politicians, and much of the general population continue to stigmatize this area, particularly with negative representations of the local youth and overall safety of the community. Political and economic stakeholders have recently taken up the task to improve the condition of the Jane and Finch area. They are now very concerned with the well-being of community members and doing-away with the negative image that has been associated with the area. Elaborating a genealogy of the rebranding, my analysis will consider the role that the neoliberalism plays in the intersectionalities 
of race, class, and gender.

\section{Theorizing Neoliberalism and the Intersections of Race, Class, and Gender}

According to David Harvey (2005) the economy of the Western world has shifted from a model of embedded liberalism to one of neoliberalism. Thatcher, Reagan and Mulroney were strong advocates for the neoliberal economic, political and social state. The basic tenents of neoliberalism are catering to the "human well-being [that] can be best advanced by liberating individual entrepreneurial freedoms and skills within an institutional framework characterized by strong private property rights, free markets, and free trade" (Harvey, 2005, p. 2). The age of neoliberalism produced a privatized and deregulated market, which created precarious employment and pockets of wealthy individuals. The state was heavily involved in maintaining the regulatory and policing apparatus that facilitated capitalist reappropriation of every facet of social life. It was believed that interest groups would sway the government to intervene in a way that would be economically beneficial for the majority (Harvey, 2005). State intervention, in terms of everyday life, was also limited as it was believed that individuals needed to be more in control of their lives. Even without direct state intervention governed subjects were created. The state monitored everything, thus creating the idea of the lurking 'big brother' who knows and sees all. Citizens were made to believe that they were in control of their own well-being, though the state ultimately held this power by indirectly governing their actions and choices.

Neoliberal ideology presupposes that all citizens are availed of an equal playing field and supposedly granted the same opportunities, regardless of their socio-economic condition. Essentially, every citizen is considered responsible for his or her success or failure as an individual or family. This self governance allowed for the welfare state to diminish. The neoliberal ideologies allowed citizens to feel liberated by thinking that they were in control of their own livelihood, whereas, in actuality, broader social and economic contexts facilitate 
governed subjects. As citizens assumed greater responsibility for their own well being, they inadvertently allowed the government to be freed of earlier levels of social responsibility. In accordance with the neoliberal framework, there is no need to provide assistance to people who can fend for themselves. Harvey asserts that "all forms of social solidarity were to be dissolved in favour of individualism, private property, personal responsibility and family values" due to Margaret Thatcher's neoliberal remarks and belief that "[there was] no such thing as society, only individual men and women" (Harvey, 2005, p. 23). While it would seem as though citizens were being granted more 'freedoms', such 'freedoms' came at the expense of forgoing the social, economic and political security that was previously offered by the welfare state. While paradoxically 'freeing' individuals, the state demanded more of its citizens in conformity, and to aid in this regard, it invested heavily in both police and prisons (Giroux, 2004).

Neoliberal ideologies permit those with economic leverage to continue to increase their wealth as a class, while those without economic stability remain exploited. Class disparity becomes more prevalent under the neoliberal regime. Urban planners have moved the impoverished outside of the city core into areas of minimal space and a high quantity of people. Inner-city areas are created to keep the under-class contained in specific areas, thus out of sight, out of mind. Bunting et al. (2004) assert that the construction or lack of space in urban areas perpetuate a culture of poverty and ghettoization.

While economic disparity may be rampant, it is not always explicitly visible, for neoliberalism homogenizes citizens as much as it attempts to 'individualize' the masses. Capitalism sells certain lifestyles, therefore, the poor and rich alike desire the same material possessions. At times, it is difficult to actually see the indicators of poverty, because it is hidden behind the material appearance of 'living well'. Furthermore, the appearance of 'wealth' can be 
seen in the spaces that have been homogenized and gentrified by large corporations. Zukin (1987) discusses the process of gentrification by middle class families in London, England, being forced to move to lower income areas. The urban poor are frequently moved from city-centres into inner-city communities or coerced to buy homes that they may not be able to afford in order for the more affluent to gentrify the space that was once home to the 'urban poor'.

This newfound attraction to the city boosts the marketization of social and cultural capital, primarily through art, music and food. Old buildings and areas are gentrified by large corporations who build condominiums, shopping malls, movie theatres, etc. Blighted neighbourhoods are revamped and recreated to promote a more modern lifestyle. Neoliberalism endorses privatization of formerly public space, in order to enhance capital accumulation and establish spaces that can be easily governed. While it may seem that the creation of quasi-public spaces such as restaurants, theatres and health facilities are being developed in lower-income areas to promote social integration, in actuality, gentrification becomes economically and socially exclusive to those that live in the neighbourhood. Zukin (1987) posits that communities cannot compete with developers, therefore, they risk losing their homes and locally owned businesses due to the vigor and rise of the private market. Gentrification leads to an increase in property value in the respective neighbourhood, which often causes the displacement of residents that once occupied the area. Once most of the residents are coerced by the market to move out of the gentrified area, more development can take place. Community members may lobby against the re-development of their neighbourhood, however, their concerns are often overshadowed by that of corporations making 'economic investments' towards 'revitalization' of the community.

Gentrification can be approached with two very different lens: one that revitalizes a community that is impoverished and one that displaces residents who are marginalized. The 
reasons for gentrification vary along the axis of social, political and economic benefits for stakeholders. Gentrification creates a geographic imagination (Fraser, 2004) of an area allows for the inclusion of some and the exclusion of others. For example, "University Heights" changes the public imaginary of the Jane and Finch area, thereby, disassociating it with fear and poverty. The development of University Heights brings with it new houses, a subway extension and possibly a new school which will inevitably change the economic framework of the neighbourhood. Slater (2004) asserts that gentrification leads to reorientation of a neighbourhood's demographic by "[moving in] the young and highly educated political and cultural activists" (p. 305). The gentrification of a neighbourhood essentially changes the social stratum that once existed causing the displacement of the underclass. The changes being made in the Jane and Finch community represent a shift towards a more gentrified and exclusive area.

The political voice of community members are often disregarded during the gentrification of neighbourhoods due to the heavy presence of corporations and community stakeholders who act as primary decision makers in the gentrification process. While neoliberalism attempts to create world citizens vis a vis globalization, it has been criticized for creating non-democratic citizens. Engin Isin and Patricia Wood (1999) define citizenship as a set of cultural, symbolic and economic practices that are aligned with civil, political and social rights and duties. The rights of citizens are at times precarious and, in the Canadian context, differ between those who identify as a 'white Canadian' and the immigrant, person of visible minority or sexual other. Even though the aforementioned groups may not be granted the same rights, they are still meant to perform the same 'duties' as a citizen, such as pay taxes. However, these citizens are meant to have a very minimal role in politics and decision-making affairs. Nonetheless, those that are taking entrepreneurial approaches to their personal lives and making attempts to engage in profit- 
able endeavors in the economy are deemed more valuable in political decision making processes.

In the next section I outline my method for examining documents that detail the process by which the re-branding project came to life in the Jane and Finch neighbourhood.

\section{Method of Inquiry}

To provide a genealogy of "University Heights" I examined documents that outlined the roles that the key social, political and economic stakeholders that played in the re-branding project. I gathered textual data available to the public via websites, newsletters and newspaper articles to forge my inquiry. The materials examined using textual analysis relate to the rebranding consist of 'official documents' disseminated by relevant stakeholders including the City of Toronto, York University, York University Development Corporation, the Toronto Transit Commission, the Toronto Community Housing Corporation, the Toronto District School Board and local community organizations. In other instances, information regarding the re-branding was not available online. To account for missing information, I met with various representatives in order to obtain additional pertinent documents. Though many insights on the re-branding project were gleaned through informal dialogue which have informed my understanding, this information is not explicitly included in my data analysis, primarily because it was garnered "off-the record" data.

The substantive lack of documentation and records indicate the minor position of the community members in decisions directly affecting their lived realities. To assess the level of community support or opposition to the re-branding involved, I explored the online responses and contacted the administration of: Jane-Finch Community and Family Centre, TD-York University Engagement Centre, Tropicana Community Services, jane-finch.com, and Jane and Finch Action Against Poverty (JFAAP). 
My genealogical framework unfolds like a roadmap and provides significant changes and events that have occurred or are yet to occur in the Jane and Finch area. The moment of origin in conducting a genealogical analysis is crucial to uncovering the many different layers of reasoning behind a project(s) development (Smart, 1985). Foucault asserts that "genealogy uncovers the eternal play of dominations, the domain of violence, subjugations and struggle" (Smart, 1985, p. 61). Uncovering the dynamics of this domination helps us to understand the relations of power that exist and reveals the struggles of those who have been subjugated.

A discourse analysis using textual data of the press releases and developmental plans regarding the re-branding initiative has enabled me to highlight the implicit messages of stakeholders. My primary sources of data are statements made, published, or authorized by the office of Ward 8 and various stakeholders. Councillor Anthony Perruzza made many public statements through advertisements, newspapers and radio talk shows that extol the benefits of rebranding the Jane and Finch area. In the context of neoliberal praxis, I use these public statements to unpack what the re-branding initiative entails and highlight whose interests it is likely to serve. Councillor Peruzza has perpetuated the idea that the Jane and Finch area is hopeless, dirty, and in need of a new image through such public statements. The re-branding project implies that the community lacks the agency to make progressive changes. To add to this effect, community members were not given an opportunity to take part in creating the new image of Jane and Finch. Most importantly, I submit that because the efforts to re-brand Jane and Finch did not involve members of the community it is lacking fundamentals of a democratic process.

To deepen my analysis I use critical race theories to investigate the neoliberal elements of the re-branding project. Critical race theory seeks to redress social inequalities by interrogating the intersections of race, class, and gender to understand race and racism through many facets 
(McMullin, 2004). I critically investigate the re-branding project from a social justice lens with the intention of understanding the position of those involved in the development of "University Heights". Despite the high sounding ideals behind "University Heights", the process of neoliberalism belies social justice by promoting privatized spaces, gentrified communities and limited community decision-making power. I demonstrate how the disregard of community voice in the decision-making process reinforces the marginalization of the "other" and undermines equality of condition. The social injustices that exist within re-branding projects are highlighted throughout my research by means of a rigorous critique of neoliberal ideology and its genealogy in Jane and Finch.

\section{Community Stakeholders}

In the following section, I will navigate through and outline the social, political and economic benefits of re-branding Jane and Finch for various stakeholders in the community. I do not make any claims that any of the following stakeholders were the direct cause of the rebranding. I am, however, providing a genealogy of the major changes that have influenced the re-branding and calling attention to the potential benefits that stakeholders are yet to reap. Moreover, this section connects the fundamental changes that are being planned by stakeholders in a larger neoliberal context.

\section{York University and York University Development Corporation}

The York University Development Corporation (YUDC) was incorporated by York University in 1985 to create "a mechanism for profitable and desirable property development" President Bud Purves stated that "commercialization helps York by providing money for endowment and capital to create much needed services such as shopping and administrative

\footnotetext{
2 www.yudc.ca 


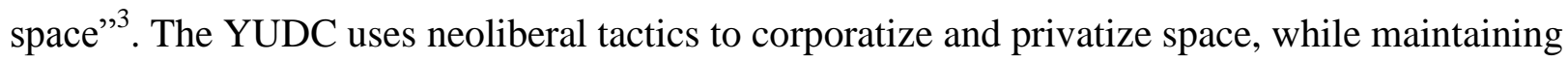
governing power of the citizens through various modes of surveillance and consumer consumption.

YUDC's current undertaking includes selling a portion of their land to Tribute Communities for the creation of the Village at York. The Village at York is located on the York University campus and is home to many faculty members and students at York. The Village at York is considered one of Toronto's newest communities. Along with creating a new and vibrant community in Toronto, Tribute Communities are also creating spaces of social exclusion by building inaffordable homes. Building new homes that are out of the price range for many creates a "spectacle", as described earlier by Baudelaire's prose, for those that are less advantaged to desire. As I have previously discussed, Harvey (2006) describes how public spaces are designed for the upper class, but simultaneously used to include and exclude people.

\section{Toronto Community Housing Corporation}

The Ontario Housing Commission built many public housing units in the Jane and Finch area in the mid-late 1960s. These houses were constructed relatively quickly, consisting of mainly high-rise apartments and town-houses. In 2001, the provincial government sold their portion of the public housing to the Toronto Community Housing Corporation (TCHC) now owns most of these properties (http://www.torontohousing.ca). As a result of poor planning and rapid development, there was a great deal of infrastructural problems with the public housing in Jane and Finch. Buildings and homes began to deteriorate, thereby creating poor living conditions.

On December 2, 2008 the TCHC released a ten-year plan geared towards repairing and

\footnotetext{
${ }^{3}$ http://www.yudc.ca/about/ 
sustaining public housing ${ }^{4}$. The TCHC plans to revitalize thirteen areas across Toronto and has designated five areas that are to be re-built: Lawrence Heights, Atkinson Co-Op/Alexander Park, Edgeley Village, Flemingdon Park, and Jamestown. Jane and Finch is one of the five listed neighbourhoods set to be revitalized. Edgeley Village, also known as Shoreham Court, is a public housing development located in Jane and Finch and borders York University. Edgeley Village is the only housing complex that is set for reconstruction in the Jane and Finch area. There are five housing developments that have been identified as having non-viable land for future development, hence, in order to proceed with development the entire complex must be broken down and re-constructed. The TCHC is constructing more of an integrated housing community and has guaranteed the same amount of social housing units. However, it is unclear where the TCHC will find space to build additional 'integrated' housing when there is limited space for social housing units. Furthermore, the question must be asked, where will the occupants of these homes go while re-construction is taking place? This re-construction will undoubtedly lead to the displacement of people and possibly homelessness, albeit temporarily. Perhaps, in the interim people would have found homes and may not want to move back, or worse, be put on a waiting list to move back into what was once their home. There are many issues that can be critically examined in terms of the new development that is being carried out by the TCHC with regards to urbanization and marginalization. Though, I want to call attention to the possible displacement of the residents in the Edgeley community and highlight that Edgeley Village is the only public housing complex in Jane and Finch that is set to be reconstructed. Edgeley Village could, in fact, be the most damaged housing complex, but it is also conveniently located next to York University. I am not suggesting that the TCHC has a hand in

\footnotetext{
${ }^{4}$ http://www.torontohousing.ca/news/RealEstateAssetInvestment2008
} 
the creating "University Heights", nonetheless, the "revitalization" of Edgeley Village is beneficial to the new image that is supposed to be created vis a vis the re-branding project.

\section{Toronto District School Board}

School closures are very intertwined with the politics to gentrify and re-brand Jane and Finch. The Toronto District School Board (TDSB) amalgamated seven school boards in 1998 as a result of Mike Harris' creation of the 'Greater Toronto Area'5. In 2009-10 the PARC (Pupil Accommodation Review Committee) reviewed ten different school communities. There were five schools under review from Jane and Finch community: Blacksmith Public School (PS), Gosford PS, Driftwood PS, Shoreham PS, and Brookview Middle School. According to the Learning Opportunity Index (LOI), four out of the five schools being reviewed in the Jane and Finch area were in the top 15 schools most in need out of 475 schools board wide in $2009^{6}$. The LOI ranks schools based on their social-economic needs. Various options were presented to the community from the PARC regarding the future of the selected schools in Jane and Finch. Options included consolidating schools and/or turning some into a K-8 model. Every option included the closure of Shoreham Public School ${ }^{7}$.

School closures in the Jane and Finch area is another example of a direct attack on impoverished communities (Keil, 2002). Community residents echoed this sentiment as the TDSB received much back lash for proposing to close schools--the lifeline in the community. Frans Bronkhorst, a parent from Gosford PS said:

\footnotetext{
${ }_{6}^{5}$ http://www.tdsb.on.ca/communications/tdsbfacts.html http://www.tdsb.on.ca/wwwdocuments/about_us/external_research_application/docs/LOI2011.pdf 7 http://www.tdsb.on.ca/wwwdocuments/schools/area_review_committee/docs/NW2_Ward_4_Ac commodation_Review_Final_Report.pdf
} 
for the school board to dare to suggest closing schools in this community - where half the parents are new Canadians who are not able to accompany their children in the learning process because they don't speak English - is discrimination against these people because of where they come from (Brown, 2010, para. 7).

For many immigrant families education is the ticket out of poverty. The symbolic closure of a school in a high needs community is devastating, however, there were many economic benefits to closing Shoreham PS. The property value of Shoreham PS is very high considering it is adjacent to Edgeley Village and minutes from York University. During community consultation meetings that I attended there were informal discussions about selling Shoreham to a private culinary college or turning it into a French school. With the new housing development by Tribute Communities more families would be entering the neighbourhood and a new schools would be needed that perhaps did not rank third on the LOI. Furthermore, after the revitalization of the Edgeley Village a new school would be beneficial for the more mixed income housing that would be built. Selling Shoreham PS would benefit the re-branding of Jane and Finch by providing the community surrounding York University with access to a new and improved school. While the school board may not have had any direct involvement in the re-branding project, the process of closing schools does fit into the larger neoliberal ploy in the Jane and Finch area.

\section{Toronto Transit Commission}

The Toronto Transit Commission (TTC) did not directly play a part in the re-branding project, however, the effects of the subway extension has had monumental impacts on the Jane and Finch community. Furthermore, extending the subway line will have a direct effect on the residents of Ward 8, in terms of the possible traffic congestion caused by everyday construction. The additional stops will be located between Keele Street and Finch (Finch West Station); Downsview Park (Sheppard West); York Boulevard and Ian Macdonald Boulevard (York 
University Station); Northwest Gate and Steeles Avenue (Steeles West Station); Highway 407 and Jane Street (Highway 407 Transitway Station); Highway 7 and Jane Street (Vaughan Corporate Centre Station).

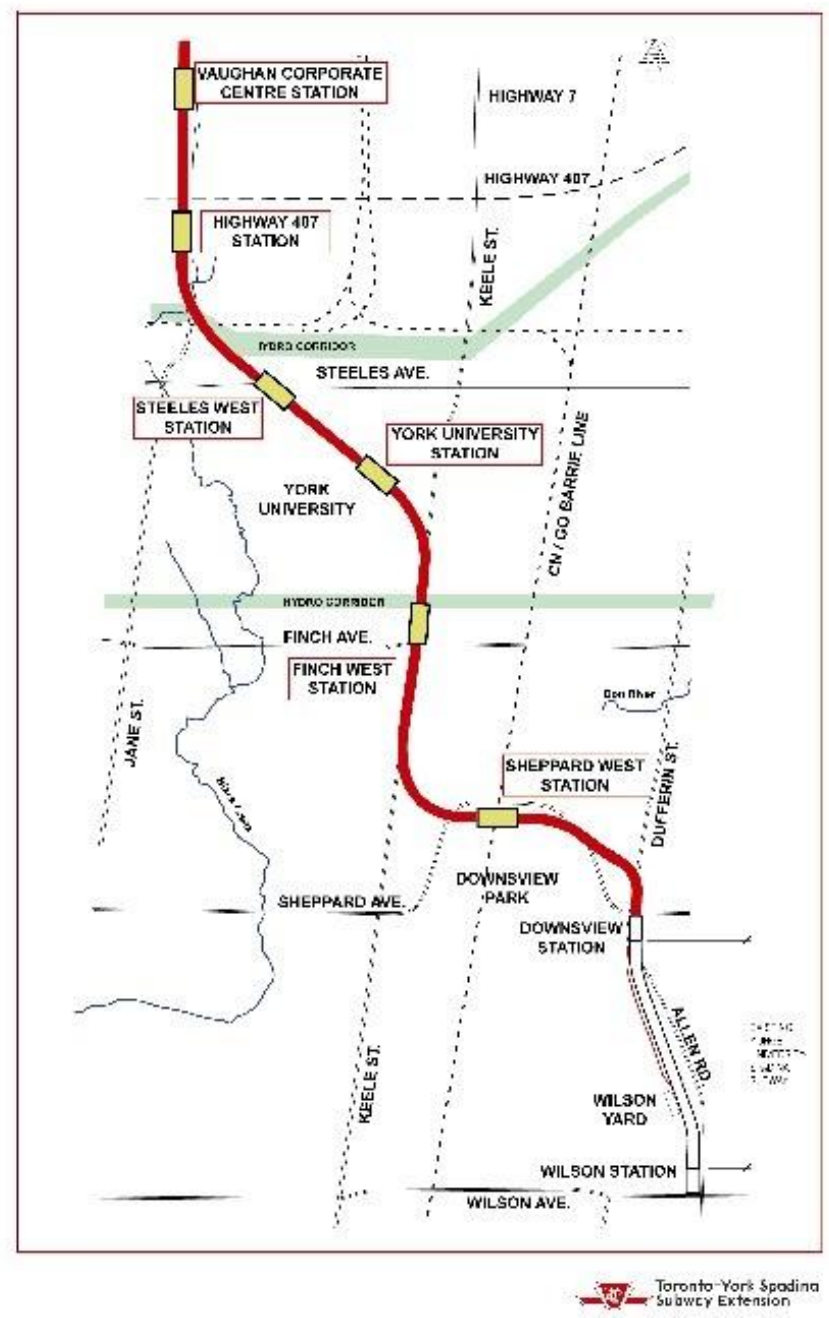

Figure 4. Map of TTC extension (Toronto Transit Commission, 2009).

The subway extension is a massive project that will be mutually beneficial to the TTC, City of Toronto, York Region, York University, developers, construction companies, and a great many of commuters. By this means economic development and increasing the taxation base would enable Ward 8 to be a municipal growth engine. Trains from each station are expected to run every four minutes, making travelling through the city easier and faster. The Finch West Station 
is estimated to be as busy as Union Station- a main transportation hub in downtown Toronto. In essence, the TTC expansion will be a major source of economic growth, whether and how marginalized residents will benefit by way of access to jobs is not all evident in any public policy documents.

Undoubtedly, the Ward 8 district will receive much attention, as a result of the anticipated subway extension. The media attention that Ward 8 received prior to the TTC extension usually involved depicting the Jane and Finch area with crime or violence. There may be a lot of pressure on Councillor Perruzza to create a safer and more welcoming image of the community, considering the large amount of endowments that Jane and Finch is going to receive to house the subway extension; there is a lot to lose if the extension is not successful. Moreover, the TTC will not want to jeopardize the safety of commuters or employees when travelling through the "crime ridden" area of Jane and Finch. In order to dissociate Jane and Finch with the stigmas of fear and give people a sense of "belonging", it is my assumption that Perruzza decided to re-brand the area to "University Heights" to alleviate the negative stereotypes and create a new image of the area. It is, nonetheless, very likely that the move to re-brand the area was initiated in part, because of the TTC subway extension.

\section{The City of Toronto}

There are many changes happening in the City of Toronto, both structurally and symbolically. After the 1998 amalgamation, Toronto shifted to become a more neoliberal, deregulated municipality. The apparent de-regulation of the municipality led to a re-regulation of the values and beliefs upheld by the municipality (Keil, 2002). Toronto saw much development in years following the amalgamation, particularly in the downtown core and in the inner cities. The City of Toronto is currently undertaking many projects to re-urbanize Toronto and encourage people to 'keep Toronto clean' via taking personal responsibility for their own mess. 
The City of Toronto has provided incentives and suggested action plans for the residents of Toronto to take part in. Some of the projected plans include planting a community garden or painting a mural. For the various projects, the City of Toronto has offered "modest grants" to the residents of Toronto. Ward 8 has worked closely with the beautification of Toronto project. In addition to facilitating local park clean-ups, Mr. Perruzza introduced an annual bike tour of “University Heights". On September 26, 2007, Perruzza held the first annual "Tour de University Heights" (James, 2007). The aim of the race was to unite the youth, members of the community with the police in order to build more trusting relationships, as well as to introduce "University Heights" to the community at large. The race is funded by Canadian Tire, the City of Toronto and the Toronto Police services; in addition the youth in the Jane and Finch area that participate, are provided with free bikes and helmets. The second annual bike race happened in September 2008, extending the race into York University campus. Shortly after the Tour de University Heights, Perruzza launched the official re-branding at Downsview Park. On May 8, 2008, Perruzza hosted a "University Heights clean-up". The clean-up took place at Driftwood Park attracting members of the community, youth from local schools, and Toronto Parks and Recreation staff. In a flyer advertised on York University's website: 


\section{Anthony Perruzza \\ COME OUT AND HELP CLEAN OUR PARK!}

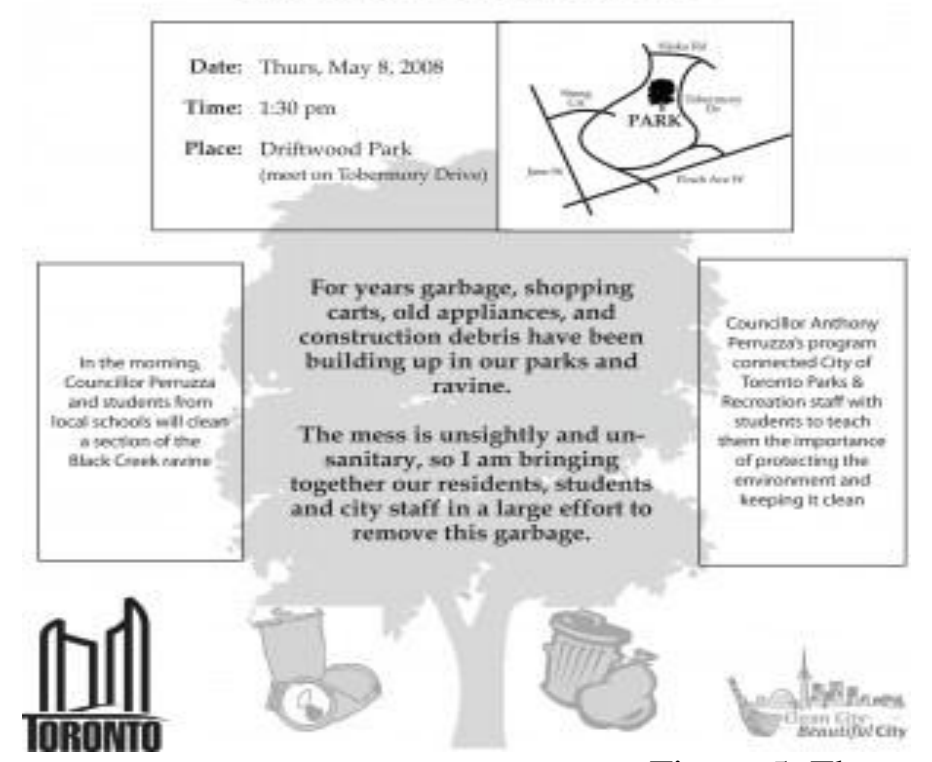

Figure 5. Flyer of Driftwood Park Clean-Up. (Institute for Research \& Innovation in Sustainability, York University, 2008).

Perruzza stresses the importance of teaching residents of the Jane and Finch area the value of protecting the environment and learning how to keep it clean. Moreover, the clean-up encourages residents to be responsible for the public park that should be maintained by the City of Toronto. The act of teaching citizens how to protect the environment and keep their 'mess' clean produces neoliberal and governed subjects who become responsible for the well-being of their living and recreational space.

\section{Various Community Perspectives of "University Heights"}

The approach that I have taken to determine if, in fact, the community supports or opposes the re-branding involved doing a general search of the organizations in the Jane and Finch community. I examined the Jane-Finch Community and Family Centre, TD-York University Engagement Centre, Tropicana Community Services, jane-finch.com, Jane and Finch 
Action Against Poverty, and the City of Toronto's Social Development Department. None of the aforementioned agencies make any claims to endorse "University Heights" in any shape or form. After much discussion with a variety of people at these agencies it was evident that the City of Toronto, particularly the Ward 8 division has a relatively close relationship with these agencies and in many cases, share the same goals for the Jane and Finch community. Most of these agencies, however, take great pride in identifying the neighbourhood that they work and live in as Jane and Finch, not "University Heights".

\section{Residents and Community Groups}

Tropicana Community Services (located in Yorkgate Mall) created a program called: Street Involve Youth Issues Coalition (Involve Youth). The Involve[ed] Youth in Jane and Finch were concerned about the re-branding project. They held a number of meetings regarding the name change. According to a newsletter from Involve Youth to other organizations in the community, a main concern brought forward by the youth was that changing the name of community will not provide solutions to the systemic problems that exist within the community, such as inadequate housing, lack of employment or educational opportunities. Tropicana Community Services wanted the community members especially the youth to have an opportunity to voice their concerns and opinions on the re-branding project. Although, the town hall meeting did not materialize, the mere co-ordination and organization of a town hall meeting from the community indicates that there was a level of concern and resistance towards the rebranding of Jane and Finch.

Jane-Finch.com conducted interviews with people regarding their thoughts and feelings towards re-branding Jane and Finch as "University Heights". The interview can be streamed on 
their website under the community videos section ${ }^{8}$. The interviews were conducted by Sabrina Gopaul and released on November 6, 2008. Seventeen people were interviewed, ranging from younger residents to older residents of the Jane and Finch community, people that have grown up in the area and a few who were just visiting. Of the seventeen people that were interviewed, only four people supported the re-branding; two people discussed both the benefits and downfalls of re-branding Jane and Finch; eleven people did not see the re-branding as solving the problems that are deeply rooted in the community. Some people saw "Jane and Finch" as being a part of their identity, Wanda McNevin expressed that “University Heights doesn't mean anything to me, it's Jane and Finch that means a lot to me" (Nguyen, 2008). Furthermore, many of the residents were upset about the amount of money that was being invested in creating "University Heights". A youth in the area questioned "why couldn't they [use] that [money] for scholarships to school?" (Nguyen, 2008). According to the video various people interviewed were unaware of the re-branding project and what it entailed. Though, a young woman from Scarborough, Ontario, who works in the Jane and Finch community, offered great insight about the rebranding:

I believe that it's the wrong thing to do...the money spent on it...could have done so many better things out here, since they talk so much crap about Jane and Finch. I believe that they asked only homeowners [about the re-branding], there [are] people that [have been] renting for a long time and [were] never asked [about] their opinion, if they want the name to be changed (Nguyen, 2008).

Thus far, there is no evidence of an open community consultation on the re-branding project.

Ultimately, based on written records, the re-branding project was void of community consensus.

Although, many community voices were missing in the process that led to the rebranding, the residents of Jane and Finch did not remain silent about the issue. Numerous agencies were involved in the organization of the special town hall meeting. Community

\section{${ }^{8}$ www.jane-finch.com


residents were aware of the re-branding issues and knew if Shoreham PS was sold it would be for private gains and stood in solidarity to ensure this did not happen. Toronto Star journalist wrote "while [PARC] meetings in all neighborhoods are emotional, board staff actually shut the January meeting in this area after parents and community members refused to break into small discussion groups to discuss various school closing options" (Brown, 2010, para. 5). A coalition of various grassroots organization in Jane and Finch formed under the umbrella Save our Schools to resist school closures. While many residents were not given an opportunity to oppose the rebranding, they ensured their voices were heard loud and clear when the issue of closing schools were concerned. The Jane and Finch area is constantly under attack by neoliberal politics. In the following sections, I will explore the many implications of neoliberalism in the Jane and Finch area, economically, politically and socially.

\section{The Neoliberal Presence in Jane and Finch}

The Jane and Finch community, or what was formally known as North York, became a part of the Greater Toronto Area (GTA) in 1998 under the Progressive Conservative government of Mike Harris. The creation of the Greater Toronto Area involved the amalgamation of the seven municipalities surrounding the city of Toronto. Premier Harris was a part of the neoconservative resurgence given impetus by the Thatcher, Regan and Mulroney era. The Harris administration embodied a neoliberal framework by privatizing and gentrifying spaces. The effects of the Harris administration are still very prevalent in the current social structure of Toronto. Roger Keil (2002) posits that the neoliberal projects that have taken place in Toronto were "frontal attacks on the poor, the left, labour and so on" (p. 588). Keil (2002) refers to the common sense revolution as 'attack[ing] the poor' because of the stringently allocated funds designated for those that were socially and economically disadvantaged during the Harris era. 
The re-structuring of Toronto is prime example of how neoliberal policies go hand and hand with producing socially exclusive spaces. First, the amalgamation was seen as a move to transform Toronto to a 'global city', in order to make bids for the 2004 Summer Olympics. Second, quasi-public agencies appropriated and gentrified spaces within the city-such as building condominiums, closing down small shops and replacing them with large retail outlets etc. Finally, the merging of seven municipalities made it difficult to allocate funds for social assistance, which left citizens with no other choice but to fend for their own 'success and failures' (Gilbert, 2004). The neoliberal shift to amalgamate the city of Toronto, on many levels, worked to displace the marginalized and the urban poor by creating spaces that were exclusive. The amalgamation led to a rise in suburbanization, gentrification and urban sprawl more generally. Affordable housing became scarce, making it difficult for the marginalized to stay in their homes or to find a home that they could afford.

The move to re-brand the Jane and Finch area has many political factors at play. The most predominant being the Toronto Transit Commission's (TTC) expansion of the subway line onto the York University campus. Extending the subway line to York's campus will provide commuters with more frequent and easy access to the university. In addition, Tribute Communities have built many new semi-detached and detached homes on York's campus. The new housing development is mutually attractive to students and professors by virtue of its location to the university and distance to the upcoming subway line. As Slater (2004) brought forward, the gentrification process always leads to the young and highly educated moving in. The benefits of the TTC expansion are plentiful to the City of Toronto, York University and Tribute Communities. There are many financial stakeholders invested in ensuring expansion of the TTC is met with success. A part of ensuring the success of the subway expansion is to 
guarantee that the citizens of Toronto and TTC employees will be safe and secure while travelling through and working in the Jane and Finch area. As constructed by popular media, the Jane and Finch community is a dangerous place to travel to and through. The best way to supposedly dismiss or ease non-Jane and Finch citizens and employees fear of danger is to create a new "Jane and Finch" one centered on York University, and simultaneously, erasing the existence of the "other".

York University borders the Jane and Finch community. There is a foot-bridge that runs along Shoreham Avenue which separates York University from Jane and Finch. Along Shoreham Avenue, east of Finch Avenue consists of an area predominantly owned by the Toronto Community Housing Commission. On the other side of the bridge is the Rexall Centre (a \$45-million tennis court at York University) ${ }^{9}$. The bridge represents a symbolic disconnect between the community and the university. Often the safety surrounding York University is related to the crime in Jane and Finch. To alleviate fear that is itself propagated by neoliberal regimes, re-branding and gentrifying spaces are important tactics for creating the image of newness and improvement.

Prior to the amalgamation of Toronto, the Ward 8 district was a part of North York. The area surrounding Ward 8 has been known as "Black Creek", "Elia", as well as "Downsview". However, it has become popularly known as "Jane and Finch" in the media and to community members. "Jane and Finch" is not the official name of the community, nor is "University Heights”. Richardson (2008) asserts that the first use of Jane and Finch was in a 1965 Toronto Daily Star (Toronto Star) article. The article discussed a single mother of eight being forced to move to a townhouse in Jane and Finch. The area became colloquially known as Jane and Finch

9 www.toronto.com/sports_recreation/listing/000-100-538 
thereafter. The official planning maps at the time designated a portion of the area as "York University Heights". Ward 8 extends from Steeles Avenue to Sheppard Avenue and Highway 400 to Finch Avenue.

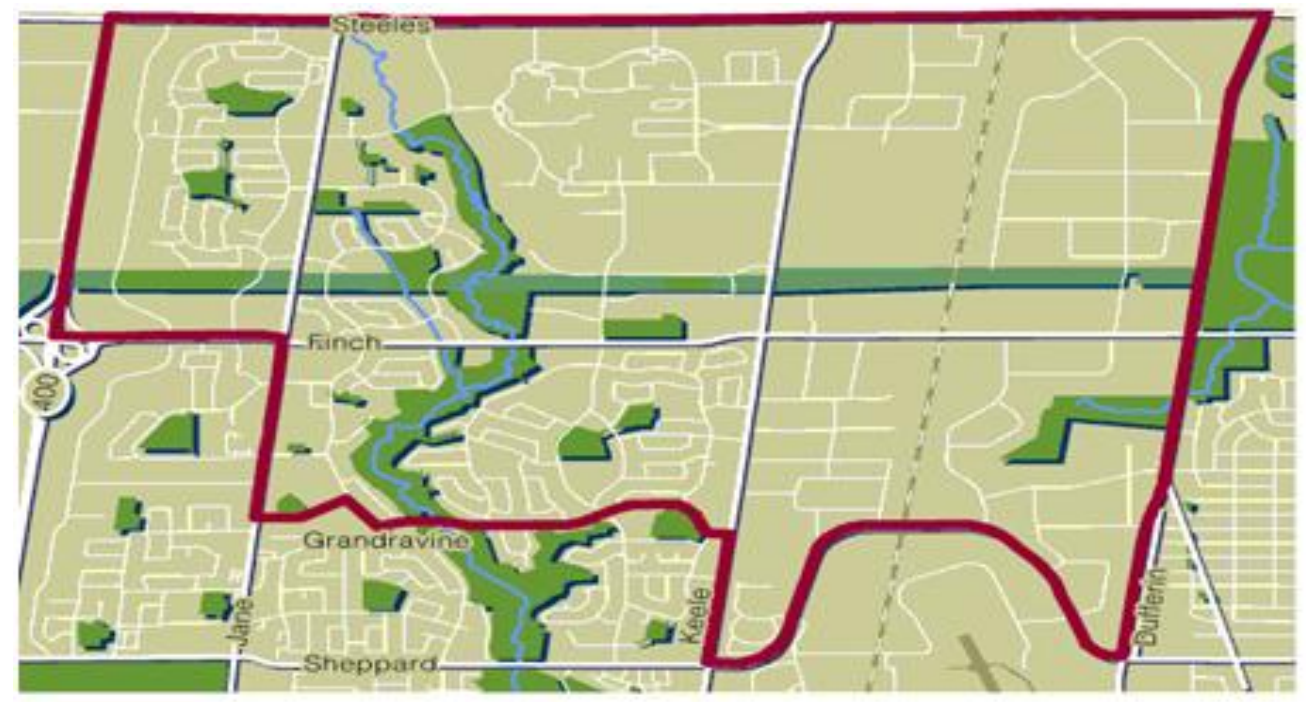

8 York West

Figure 1. Map of Ward 8, 2000. (City of Toronto, 2000)

According to Nick Aveling (2009), a Toronto Star columnist, many residents feel a great sense of pride in the brand "Jane and Finch" and about their community in general. In a radio interview on the John Oakley Show, Anthony Perruzza argues that according to the youths he spoke to: "young folks have trouble getting jobs, when they tell their employers that they are from the Jane-Finch area" (January 13, 2009, AM 640). Perruzza claims that his desire to rebrand the area is to help create a new image of Jane and Finch, one that people can feel proud of. Re-branding Jane and Finch to "University Heights" will enable young residents to take responsibility for their (un)employability.

During the 2006 municipal elections Mr. Anthony Perruzza proposed re-instating the "University Heights" title in the Jane and Finch area.The re-branding project used a former Ward 8 designation to re-brand the Jane and Finch area. There was no need for any legislative changes 
to be made in re-branding the area, because "University Heights" was formerly used to describe a portion of Ward 8. Therefore, a formal discussion of the symbolical changes being implemented in Jane and Finch was not on the municipal agenda, as it did not deal with any structural or by-law changes. There are no official minutes of when exactly the move to re-brand occurred, nor any identification of the decision-makers that took its conceptualizations. The consultation process that emerged from Mr. Perruzza's platform appears to have been informal.

The City of Toronto and York University seem unconcerned with how the re-branding of Jane and Finch to "University Heights" will affect the citizens in the neighbourhood. My use of the term 'unconcern' is attributed to the lack of community consultation regarding the rebranding. I do not want to suggest that the re-branding project is merely a good idea that can go bad; rather it is a project that is fundamentally based in a set of assumptions that has a collateral effect and amplification of fragmented economic conditions in the community. Public spaces are slowly being appropriated by quasi-public agencies in neoliberal fashion, through projects that are currently being undertaken by the City of Toronto, the TTC, and York University Development Corporation, such as the re-branding of Jane and Finch, building a new housing complex on the outskirts of the community and extending the subway line.

Making the connection: The effects of race, class, gender and neoliberalism in re-branding Jane and Finch

The re-branding project and, more generally, the presence of neoliberalism in Jane and Finch, can be demonstrated along the axis of race, class and gender. I would like to give the Ward 8 district the benefit of the doubt and consider that the re-branding project is being enacted with the residents of Jane and Finch in mind. According to Statistics Canada 2006, there are $31.3 \%$ of lone-parent households in Ward 8, while only $20.3 \%$ in all of Toronto. For the most 
part, the majority of these households are led by women. The struggle and resilience of single mothers and women in general, in the Jane and Finch community is extraordinary, by any measure. To consider how the re-branding project will benefit the residents in the Jane and Finch community, it is pivotal to understand how the lives of women, particularly single mothers, will be enhanced. Single mothers are often blamed for the negative stereotypes and the perpetuation of violence that occurs in the area, because they are seen as the producers of unruly youth. Paul Gilroy argues that black women "are directly in the firing line...because they are seen as playing a key role in reproducing the alien culture and, secondly, because their fertility is identified as excessive and therefore threatening" (Sibley, 1995, p. 108). It is easy to place blame on single mothers for not ensuring their children to do not partake in violent activities. Marginalized women are seen as perpetuating the violence in society by continuing to have children, without, ostensibly, being able to provide them with adequate support. It is easy to blame single mothers for not providing enough support and guidance for their children, however, a consideration must be made to the fact that many single moms are forced to work two or three jobs in order to make ends meet, so perhaps they do not have the privilege to spend their mornings "checking up" on their children. After working at paid employment, these single mothers must also participate in the unpaid labour market; spending quality time with their children becomes a scarce commodity. Brand (1993) brings our attention to the fact that, racialized women often become caretakers for upper-middle class white families, while their own children are left to take care of themselves. The problems that single mothers face in Jane and Finch are far ranging and very systemic, though, they should not be ignored.

Many single mothers in Jane and Finch are trapped in the same system that is designed to help them: Ontario Works. Ontario Works, also known as social assistance, perpetuates the 
cycle of poverty. Shazia, a single mother living in the Jane and Finch area spoke about the hardships of living on Ontario Works at the release of the 2007 Welfare Incomes at Driftwood Community Centre in Toronto. Shazia put forward that:

breaking the cycle of poverty requires more than the handout of a monthly pay check and training for low-end job[s]... after over a decade of bouncing from one dead end job to another, on and off Ontario Works... [I realized] that Ontario Works lacked the resources and tools to assist in breaking my cycle of poverty" (Women Moving Forward, 2008, p. 5).

Although the mothers are blamed for causing and continuing to contribute to the violence in the Jane and Finch area by, as Gilroy suggests, 'reproducing an alien culture', the real perpetrator is the poverty that infiltrates the lives of these families. If the Ward 8 district truly wants to create a new image of Jane and Finch, it is vital to identify the deep systemic issues that affect the lives of its residents and work from that point to find solutions to break the chains of poverty and violence.

The over policing of priority neighbourhoods in Toronto through programs such as Toronto Anti-Violence Intervention Strategy (TAVIS) leads to ongoing racial profiling and marginalization ${ }^{10}$. TAVIS is a program initiated by the Toronto Police to prevent crime and violence in high priority areas. Youth, as a result of TAVIS, become "known to police" at earlier ages. TAVIS often uses the guise of empowerment to go into schools in order to build a rapport with students and begin the process of criminalization. Following Julian Falconer's 2008 report of the Toronto District School Board, entitled "The Road to Health: A Final Report on School Safety", fifty Toronto high schools were set to have police presence in their schools; Westview Centennial Secondary School (a local Jane and Finch high school) is one of them ${ }^{11}$. However, the community is in strong opposition to having uniformed police officers present in the high

\footnotetext{
${ }^{10} \mathrm{http}: / / \mathrm{www} \cdot$ torontopolice.on.ca/tavis/

${ }^{11}$ http://www.cbc.ca/canada/toronto/story/2009/06/29/toronto-officer-schools.html
} 
school; Sky Starr, a Westview parent, gathered 400 signatures of residents who are against police in the local school (Marlow, 2009). In the Racism, Violence and Health Project carried out by Jennifer Clarke and Janice Acton (2004), a youth from Jane and Finch describes his experiences of racism and his relationship with the police:

Racism affects me personally because I'm a Black male living in Jane-Finch...Everyday you are stressed because you can be stopped by police. Even if you walk the streets around your house you feel unsafe (Acton and Clarke, 2004, section 3).

In a 1983 documentary about Jane and Finch called: “A Home Feeling: Struggle for Community", there were numerous young, black men who also express the sentiment of being detained by the police for no apparent reason, which often led to them being harassed and habitually taken to jail. The mistrust that exists between the youth and the police stems from a long history of mistreatment; it will take much more than the brand "University Heights", a bike race, or police presence in the high schools to repair these deep emotional, psychological and physical trauma.

The promotion of "University Heights" has also set a class divide between the haves and the have nots. Symbolically, we are able to see this divide through the image that is being represented on the "University Heights" banners hung along on the perimeters of Jane and Finch: 


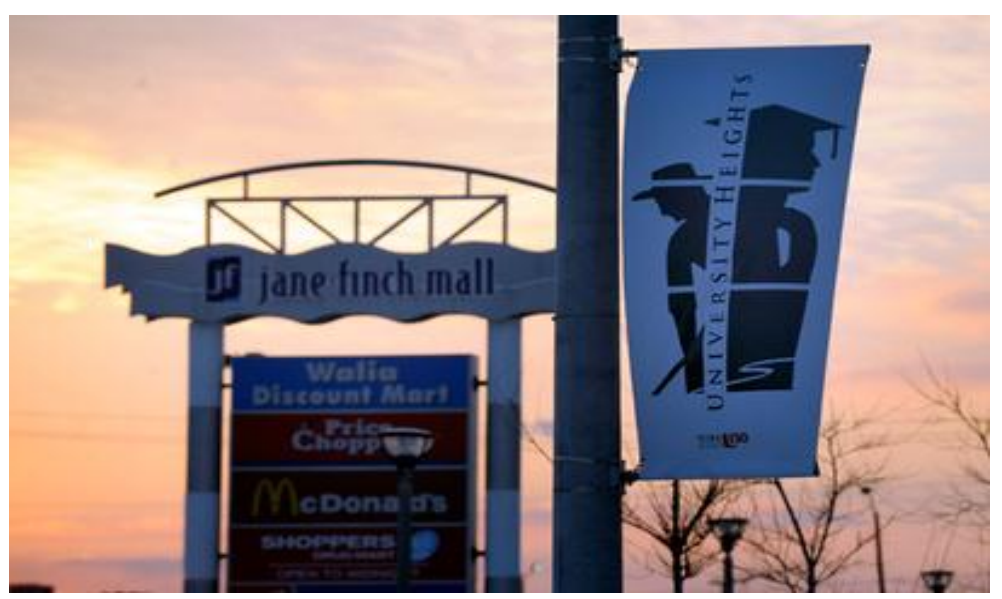

Figure 6. University Heights Banner. (Aveling 2008).

The banner promoting "University Heights" depicts a farmer and a student. The student is wearing a graduation cap and is placed slightly above the worker. The banner suggests that the student is higher than or in a better position than the farmer. Conversely, in the banner, the student's position is dependent on the farmer's role. Eric Olin Wright explains exploitation as "the material welfare of one group of people casually depends upon the material deprivations of another" (McMullin, 2004, p. 21). The privilege of attending university is not always granted to those in the Jane and Finch area. Although, "University Heights" is being branded as a university community, the reality is that not many people are able to pursue post-secondary careers. According to Statistics Canada 2006, only $20 \%$ of residents in the Ward 8 district have a university degree. Furthermore, many young people in the area are streamed into career paths and not university careers. Shazia- a participant of Women Moving Forward- revealed that when she told her social worker about her aspirations to pursue a university career, she was told that university would be an impossible choice for a single mother (Women Moving Forward, 2008). A university career is often not the first option being offered to many young people through their guidance counselors, teachers, and even social workers. Anthony Perruzza suggests that the "the banners are connecting a community on the move to a new image" (Vincent, 2008, para. 9). 
However, the banner presents depicts a lifestyle that is not available to many, while still asserting that the working class will always be below the educated class. The banners were meant to unify the community; instead it works to further segregate the classes.

\section{Final Considerations}

This paper has worked to demonstrate the social injustices that arise from re-branding, as well as, the benefits for various stakeholders. Moreover, this paper calls attention to the neoliberal politics that impact the lives and livelihoods of residents in Jane and Finch vis a vis rebranding. The creation of "University Heights" further marginalizes a marginalized community. Much of the rhetoric surrounding the re-branding suggest that the title "University Heights" will allow residents to feel a sense of belonging and to feel proud of their neighbourhood, thus, reshaping and re-instating their ability to belong and participate in cultural, socio-economic, and political life of the Jane and Finch community. The premise of the re-branding project is to provide residents with a sense of belonging, Carol Pateman (1970) asserts that participation and community involvement precedes any type of belonging that can exist in a community. Beyond informally speaking to residents, there is no public evidence of community consultation with respect to re-branding the neighbourhood to "University Heights". There are no paper trails of when meetings were held to discuss the re-branding. Although, discussion of the re-branding project may have emerged during town hall meetings, there are no official minutes that have been documented to that effect.

Councillor Perruzza claims that rebranding the Jane and Finch community as "University Heights" will serve to "commemorate the historic names of our neighbourhood" (Perruzza, 2009); however, only a small portion of the Jane and Finch community is considered "University Heights". Furthermore, the title "University Heights" was implemented prior to the 1960s, 
during a time when the community was much more homogenous than it is currently. Therefore, dusting off the old label of "University Heights" can be considered as a revisionist approach to creating a new image of Jane and Finch. The term "University Heights" was used in the original development plans that led to the creation of densely populated spaces. Not only was the area poorly constructed, it also promoted racial and economic segregation by having such a high portion of subsidized housing in one area (Galabuzi, 2006). As previously discussed, the TCHC acknowledges the poor infrastructure in the Jane and Finch community due to OHC development; albeit problematic, the TCHC is attempting to repair these damages structurally and symbolically. The history being commemorated is based on a revisionist past which fostered social injustice and racialization. The perpetuation of injustice can be seen through the process of gentrification. Many residents will eventually be displaced from the Jane and Finch area with the re-construction of Edgeley Village and the development of Tribute Communities. Those that do remain will be highly surveilled bodies with the implementation of more security cameras and heavily policed areas through programs such as TAVIS. It is questionable if Jane and Finch is being re-branded to improve the socio-economic and political condition of residents in the area, because as has been demonstrated through the genealogy section the re-branding will explicitly benefit the developers, provide an expanded tax base for the city and more revenue to the TTC. The re-branding project serves to cover up the many levels of racial injustice that occur towards the residents in Jane and Finch. The racialization of Jane and Finch has become a double edged sword. On one hand, there is a degree of marginalization towards those residents who reside in the Jane and Finch corridor; on the other hand, this space provides an opportunity for people to feel like they belong somewhere. If one chooses to move out of a racialized space, often, they face another degree of marginalization. Sibley (1995) expresses the theories of W. E. 
B. DuBois, who describes the plight of moving out of racialized spaces:

[the marginalized person] who ventures away from the mass of [their] people and their organized life find [themselves] alone, shunned and taunted, stared at and made uncomfortable... [they] remain far from friends... and feel in all its bitterness what it means to be a social outcast (p. 146).

Even if someone moves out of the Jane and Finch neighbourhood, often they move into another racialized area. Though, there are some who move to middle class neighbourhoods, but again are made to feel 'othered' in those spaces as well. The racialized person carries on them the burden of being marginalized where ever she or he may go. One can choose to stay in a community with inadequate housing or, if they can afford it, could move out and face another type of ostracization. Sibley (1995) affirms that the racialized landscape is both of the body and the land. Racism is pervasive in the lives of the Jane and Finch residents, perhaps not always between community members, but between community members and their employers, colleagues, and even friends who do not live in the area. Sibley (1995) asserts that racialized persons are subjected to racial and cultural assumptions that add to the many layers of racism that they may already face that take the form of racial slurs, harassment, or profiling.

The landscape of Jane and Finch has been plagued with much negative media representation. Richardson (2008) demonstrates that the media coverage of Jane and Finch is often related to crime or violence. If the only stories that are being told regarding the Jane and Finch community are ones that involve crime, inevitably the area will be considered "unsafe". Jane Jacobs (1961) asserts that it only takes a few incidents of violence or violent representations to create urban fear on city streets. Once a street has been deemed unsafe "people will fear the streets...and use them less, which make the streets...more unsafe" (Jacob 1961:30). The urban fear of city streets is strongly correlated with racialized bodies; people fear unsafe spaces and its 
association with the "other". Re-branding Jane and Finch to "University Heights" will create a new image; however, this new image will not dissociate the area with fear. As Councillor Perruzza makes clear the radio interview "Jane and Finch is an intersection and that intersection will continue to exist" (January 13, 2009, AM 640). Re-using the name "University Heights" will create a façade of new image, but will not change the problems that exist within the Jane and Finch area. The goal of the re-branding project is twofold: it attempts to create an image of a 'safer' Jane and Finch, one in which outsiders would feel safe travelling through; it is also trying to create a new type of insider by gentrifying the space and insisting that residents begin to take more responsibility for their individual circumstances and living conditions.

The TTC expansion into Jane and Finch area will undoubtedly lead to an increase in the number of surveillance cameras in and around the area to ensure the "safety" of the commuters. In an attempt to create more governed subjects, there have been surveillance cameras installed at the intersection of Jane and Finch to "enhance security". The idea of surveillance suggests that there is always a force lurking to maintain proper behaviour and social control in public spaces (Harvey, 2006). A highly surveilled area will supposedly help the City of Toronto, York University, and the TTC regain and maintain control of the Jane and Finch area. In actuality, the re-branding project serves to assist the aforementioned stakeholders' control of the area and reestablishes private land owners' sense of 'belonging' in Jane and Finch.

The underlying mission to revamp the Jane and Finch area is to create a new image, in this case, one that is not associated with fear or with immigrants, troubled youth, visible minorities, or any identity associated as the "other". In order for the City of Toronto, YUDC and the Toronto Transit Commission to make socio-economic and political gains from the rebranding initiative, they must regain social control of the area to create an image of safety that 
will encourage commuters to travel into Jane and Finch and possibly take up residence in the area. The YUDC profits from Tribute Communities buying the vacant land on York University's property; Tribute Communities in return, makes a profit from the new home owners; and the City of Toronto gains revenue from the new property tax payers. Much of the Jane and Finch area is predominantly owned by the Toronto Community Housing Corporation (TCHC). The TCHC could potentially sell their property to private builders, such as the Tribute Communities, in which case residents will be forced out of the area. The possibility of the TCHC selling their land to Tribute Communities leads to a precariousness in housing security for tenants living in TCHC homes. If residents are displaced from the Jane and Finch area, there are very limited alternatives for affordable housing. One of the most problematic aspects of neoliberalism is that it promotes gentrification projects such as "University Heights", which lead to the displacement of the economically marginalized. The gentrification of a community causes an increase in property value, as well as cost of living in that area. Consequently, gentrification projects add another layer of stress for those that are economically marginalized in any community.

Beyond the jeopardy of gentrification there is also the symbolic imagery of "University Heights" that is problematic. Dusting off an old title of the community will not obliterate the negative stereotypes that have been associated with the area. The projection of "University Heights" reifies the stigmatized reputation of Jane and Finch. Stephanie Payne, a Toronto District School Board Trustee of the schools in the Jane and Finch area, makes a reference to Shakespeare, but says it best, "a rose by any other name is still rose" (Aveling, 2009, para. 6). Changing the name of Jane and Finch does not change the socio-economic or political conditions that exist in the area. It is pivotal to represent and highlight the non-violent aspects of the area in a manner that is not imposed as a top-down initiative to counteract the stigmatized reputation 
that is connected to the Jane and Finch area and its residents. Trying to positively depict Jane and Finch requires community input and consultation, in order to be effective. There are many grassroots organizations, services, and activists in the community who use the brand "Jane and Finch" to promote the agency, resilience and strength of the community and its residents.

The "University Heights" brand reaffirms the negative stereotypes that have been associated with Jane and Finch, instead of working towards finding solutions for the systemic issues that the community faces. Providing resources in the Jane and Finch area based on what the community identifies as a need through community consensus will heighten the 'sense of belonging' that Councillor Perruzza is aiming to achieve with "University Heights". Investing in education and the grassroots organizations in the Jane and Finch area is critical to promoting change and social justice. Creating a new image of the Jane and Finch area by using "University Heights" as a brand serves to disconnect and isolate local residents from belonging within this space, thus enabling further gentrification by making way for new residents to claim this space. Moreover, the re-branding project keeps local residents stagnant and marginalized in their socioeconomic positions. By virtue of the political disregard of community voice, the re-branding of Jane and Finch to "University Heights" acts as new form of colonization by trying to transform the space into an area that is more "hopeful" as Councillor Perruzza suggests (Ros, 2007). The fundamental logic, process and outcomes that are signified by rebranding are ones that undermine radical social participation and the achievement of equality of condition. 


\section{Works Cited}

A \$1 million 'front door' for York in Jane-Finch. (n.d.). Retrieved January 8, 2009 from http://www.yorku.ca/yfile/archive/index.asp?Article=7184

Anderson, Kay. (1998). Sites of Difference: Beyond a Cultural Politics of Race Polarity In "Cities of Difference". New York: The Guildford Press

Aveling, Nick. (2009). Rebranding Jane and Finch. Toronto Star, January 8. Retrieved on January 10, 2009 from http://www.thestar.com/News/GTA/article/563486

Bannerji, Himani. (2002). Inventing Subjects. London: Wimbledon Publishing Company

Bannerji, Himani. (2005). Building from Marx: reflections on class and race. Social Justice, 32 (4): $144-162$

Bean, Kellie. (2003). Coulter's Right-Wing Drag. The Free Press, October 29. Retrieved May 28, 2009 from http://www.freepress.org/departments/display/20/2003/441

Brand, Dionne. (1993). In Returning the Gaze. Toronto: Sister Vision Press

Brown, Louise. (2010). Angry Parents Oppose School Closures. Toronto Star, February 21. Retrieved on February 25, 2010 from http://www.thestar.com/news/gta/article/767828--angry-parents-oppose-school-closings

Bryman, A., and Teevan, J.J. (2005). Social Research Methods. New York: Oxford University Press.

Bunting, Trudi et al. (2004). Uneven Geography of Housing Affordability Stress in Canadian Metropolitan Area. Housing Studies 19 (1): 361-393

City of Toronto: The Clean and Beautiful City, (n.d.). Retrieved July 10, 2009, from http://www.toronto.ca/cleanandbeautiful/about.htm

Clarke, Jennifer and Acton, Janice. (2004). Racism is layers and layers of things that break your spirit and damage your community. Halifax: Dalhousie University

District 10 Draft Plan. (May 1967). North York Planning Board. North York Public Library: Urban Affairs Section.

Eyerman, Ron. (2004). The Past in the Present: Culture and the Transmission of Memory. Sage Publications, Ltd.: Acta Sociologica, Vol. 47, No. 2 (Jun., 2004), pp. 159-169.

Fifty Toronto high schools to have police presence. (n.d.). Retrieved July 3, 2009 from http://www.cbc.ca/canada/toronto/story/2009/06/29/toronto-officer-schools.html 
Flyer of Driftwood Park Clean-Up (n.d.). Retrieved May 30, 2009 from http://www.yorku.ca/irisinfo/wp

Foucault, Michel. (1980). Two Lectures, in Power/Knowledge: Selected Interviews and Other Writings 1972-1977. New York: Pantheon Books.

Foucault, Michel. (2003). The Essential Foucault: Selections from the Essential Works of Foucault 1954-1984. Edited by Paul Rainbow and Nikolas Rose. New York: The New Press

Fraser, James. (2004). Beyond Gentrification: Mobilizing Communities and Claiming Space. Urban Geography, 25 (5): 437-457

Fraser, Nancy. (2009). Scales of Justice. New York: Columbia University Press

Galabuzi, Grace-Edward. (2006). Emerging Realities and Old Problems in Canada's Economic Apartheid: The Social Exclusion of Racialized Groups in the New Century. Toronto: Canadian Scholars' Press Inc.

Gilburt, Liette. (2004). At the Core and on the Edge: Justice Discourses in Metropolitan Toronto. Space and Polity. 8(2): 245-260.

Giroux, Henry. 2005. The Terror of Neoliberalism. Literature, Vol. 32, No. 1 (Winter, 2005), pp. 1-19

Hagan, John. (1994). Crime and Disrepute. Thousand Oaks: Pine Forge Press

Harvey, David. (2005). A Brief History of Neoliberalism. Oxford: Oxford Press

Harvey, David. (2006). The Political Economy of Public Space in The Politics of Public Space. New York: Routledge Press.

Isin, Engin and Wood, Patricia. (1999). Citizenship and Identity. London: Sage Publications

Jacobs, Jane. (1961). The Death and Life of Great American Cities. New York: Random House

James, Royson. (2007). Jane-Finch races to reinvent itself. Toronto Star, September 28, 2007. Retrieved January 9, 2009 from http://www.thestar.com/News/article/261422

Jane-Finch.com. (n.d.). Retrieved January 6, 2009 from http://www.jane-finch.com

Keil, Roger. (2002). Common Sense Neoliberalism, Progressive Conservative Urbanism in Toronto, Canada. Antipode 34 (3): 578-601.

Leitner, Helga; Peck, Jamie and Sheppard, Eric. (2007). Contesting Neoliberalism Urban Frontiers. New York: The Guilford Press. 
Low, Setha and Smith, Neil. (2006). The Politics of Public Space. New York: Routledge Press.

Map of Ward 8. (n.d.). Retrieved July 15, 2009 from http://www.toronto.ca/wards2000/images/ward08.gif

Marable, Manning and Mullings, Leith. (2003). Let Nobody Turn Us Around: Voices of Resistance, Reform, and Renewal. Lanham: Rowman \& Littlefield Publishers, Inc.

Marlow, Iain. (2009). Jane-Finch fights plan to put police in high school. Toronto Star, September 5. Retrieved September 7, 2009 from http://www.thestar.com/article/691388

Miller, David. (2009). City of Toronto: Clean and Beautiful City, Mayor's message. Retrieved July 10, 2009 from http://www.toronto.ca/cleanandbeautiful/mayor.htm

Mitchell, Don. (1995). The End of Public Space? People's Park, Definitions of the Public, and Democracy. Oxford: Annals of the Association of American Geographers, 85 (1), pp. 108-133

McMullin, Julie. (2004). Understanding Social Inequality: Intersections of Class, Age, Gender, Ethnicity and Race in Canada. Toronto: Oxford University Press Canada

North York Community Council Minutes. (n.d.). Retrieved July 13, 2009 from http://www.toronto.ca/legdocs/2009/agendas/ny.htm

Nguyen, Paul. (2008, November 16). Re-branding Jane and Finch to University Heights Video. Retrieved December 29, 2008 from http://www.jane-finch.com/videos/rebranding.htm

Oakley, John. (2009, January 13). The Jane and Finch area being rebranded as University Heights on AM 640 (radio)

Pateman, Carol. (1970). Participation and Democratic Theory. Cambridge: Cambridge University Press

Perruzza, Anthony. (2009). City of Toronto Councillor Newsletter. Toronto: City of Toronto, Ward 8,Volume III.I

Ravelli, Bruce and Webber, Michelle. (2010). Exploring Sociology. Toronto: Pearson Education Canada

Razack, Sherene. (2002). Race, Space and the Law. Toronto: Between the Lines. 
Rexall Centre. (n.d.). Retrieved September 5, 2009 from http://www.toronto.com/sports_recreation/listing/000-100-538

Richardson, Christopher. (2008). Canada's Toughest Neighbourhood: Surveillance, Myth and Orientalism in Jane-Finch. St. Catharines: Brock University, Faculty of Humanities and Social Sciences

Ros, David. (2007). Jane and Finch to become University Heights. Excalibur Press, October 16. Retrieved February 5, 2009 from http://jane-finch.com/files/excalibur_janefinchtobecomeuniversityheights.pdf

Sibley, David. (1995). Geographies of Exclusion. London: Routledge

Slater, T. (2004). Municipally managed gentrification in South Parkdale, Toronto. Canadian Geographer. 48 (3): 303-325

Smart, Barry. (1985). Michel Foucault. Sussex: Ellis Horwood Limitied

Solomon, Patrick; Portelli, John; Daniel, Beverly-Jean; Campbell, Arlene. (2005). The discourse of denial: how white teacher candidates construct race, racism, and 'white privilege'. Race, Ethnicity and Education. Vol.8, No.2, July 2005, pp. 147-169: Toronto.

Statistics Canada. (2006). City of Toronto Ward Profiles. Retrieved June 2, 2009 from http://www.toronto.ca/wards2000/ward8.htm

Sze, Julie. (2007). New York City Environmental Justice Campaigns: Stigma, Blight, and the Politics of Race and Pollution in Noxious New York: The Radical Politics of Urban Health and Environmental Justice. Cambridge: MIT Press. (pp: 49-90).

Teelucksingh, Cheryl. (2007). Environmental Racialization: Linking Racialization to the Environment in Canada. Local Environment: Vol. 12, No. 6, 645-661, December 2007

Toronto Community Housing Corporation, (n.d.). Retrieved July 6, 2009, from http://www.torontohousing.ca

Toronto Transit Commission. (n.d.). Retrieved July 30, 2009 from http://www3.ttc.ca

Toronto Transit Commission Subway Extension Map. (n.d.). Retrieved August 3, 2009 from http://www3.ttc.ca/About_the_TTC/Projects_and_initiatives/Spadina_subway_extension/ index.jsp

Tropicana Community Services. (n.d.). Retrieved July 20, 2009 from http://www.tropicanacommunity.org/main/home.html 
Vincent, Donovan. (2006). Police to watch York West polls. Toronto Star, November 8. Retrieved June 10, 2009 from http://www.thestar.com

Vincent, Donovan. (2008). Banners 're-brand' Jane-Finch. Toronto Star, October 17. Retrieved January 10, 2009 from http://www.thestar.com/News/GTA/article/519006

Walters, Ronald. (2008). The Price of Racial Reconciliation. The University of Michigan Press: Michigan

Ward 82006 Election Results. (n.d.). Retrieved July 27, 2009 from http://app.toronto.ca/epr/eprDetail.do?008

Women Moving Forward. (2008). Annual Report to Stakeholders. Retrieved August 13, 2009 from http://www.womenmovingforwardcanada.org

York University Development Corporation, (n.d.) Retrieved June 6, 2009 from http://www.yudc.ca/Home/index.html

York University Secondary Plan. (2006). City of Toronto, June 2006. Retrieved July 3, 2009 from http://www.toronto.ca/planning/official_plan/pdf_secondary/10_york_university_june200 $\underline{6 . p d f}$

York University-TD Community Engagement Centre. (n.d.). Retrieved July 14, 2009 from http://www.yorku.ca/cec

Zukin, Sharon. (1987). Gentrification: Culture and Capital in the Urban Core. Annual Review of Sociology, Volume 13: 129-147 